\title{
Correspondence
}

\section{Aqueous humour lactic dehydrogenase isoenzymes in retinoblastoma}

TO THE EDITOR, British fournal of Ophthalmology

SIR, Since submitting our paper for publication, we have become aware of additional relevant information we wish to bring to your attention.

We have had the opportunity to study two patients whose aqueous humour assays are at variance with our previously-reported findings. One patient, with histologically proved retinoblastoma had a total aqueous humour $\mathrm{LDH}$ of $2303 \mathrm{iu} / \mathrm{l}$ and a ratio $\mathrm{LDH}_{5}: \mathrm{LDH}_{1}$ of only $1 \cdot 9$. The other patient, with bilateral congenital/ non-rhegmatogenous retinal detachment and no retinoblastoma, had total aqueous humour LDH levels of 194 and 19, and ratios $\mathrm{LDH}_{5}: \mathrm{LDH}_{1}$ of 24 and 30 .

A recent paper (Swartz, Herbst, and Goldberg, 1974) supported the original hypothesis of Dias, Senthe Shanmuganathan, and Rajaratnam (1971) that retinoblastoma is associated with an elevated total aqueous humour LDH, and referred to a paper by Kaneko and Suzuki (1972) who found (as we did) that, although the total aqueous humour LDH was inconsistently raised in retinoblastoma, in seven cases all were associated with an elevated $\mathrm{LDH}_{3}$ isoenzyme (and to a lesser extent $\mathrm{LDH}_{2}$ and $\mathrm{LDH}_{4}$ fractions).

We believe that the aqueous humour $\mathrm{LDH}$ assay is currently a valuable diagnostic adjunct in the diagnosis of retinoblastoma, in that both an absolute elevation of the total aqueous humour LDH and a relative elevation of the slow isoenzyme fractions-that is, a shift to the right-appear to be suggestive but not diagnostic of retinoblastoma. We wish to encourage further experience with this test to resolve the inconsistencies in the literature, and to define more accurately the limits of reliability and scope of application of this biochemical assay. Yours faithfully, PAUL E. ROMANO and JACK KABAK

The Children's Memorial Hospital, 2300 Children's Plaza,

Chicago,

Illinois 606 14, USA

(Undated, received I 3 September 1976)

\section{References}

DiAS, P. L. R., SENTHE ShaNMUganathaN, S. S., and RAJARATNAM, M. (1971) Brit. F. Ophthal., 55, r30 KABAK, J., and ROMANO, P. E. (1975) Ibid., 59, 268 KANEKo, A., and SUZUKI, H. (1972) Acta Soc. Ophthal. jap., 76, 672

SWARTZ, M. S., HERBST, R. W., and GOLDBERG, M. F.

(1974) Amer. F. Ophthal., 78, 612

\section{Notes}

\section{International Course in Ophthalmology}

\section{Barcelona, 15 to 20 May 1977}

The VII International Course in Ophthalmology at the Barraquer Institute will be held in Barcelona at the Pelacio de Congreso de Barcelona.

\section{Congreso Argentino de Oftalmologia}

\section{Mar del Plata, Argentina, 2 to 8 November 1979}

Further information may be obtained from Dr Hugo D. Nano, Secretario General, XI Congreso Argentino
The appointed agents are: Atlas Express, SA, Pasco de Gracia 83, Barcelona 8, Spain, from whom further information may be obtained.

de Oftalmologia, Casilla de Correo 736r7600 Mar del Plata, Argentina. 